\title{
PENGARUH METODE PEMBELAJARAN BRAINSTORMING TERHADAP KEMAMPUAN PEMECAHAN MASALAH MATEMATIKA SISWA PADA MATERI SPLDV DI KELAS VIII SMP NEGERI 15 AMBON
}

\author{
Ayu S. Tuarita, J. S. Molle, A. L. Palinussa* \\ ${ }^{1,2,3}$ Program Studi Pendidikan Matematika FKIP Universitas Pattimura Ambon \\ Corresponding author: A. L. Palinussa \\ *andersonpalinussa@gmail.com
}

\begin{abstract}
ABSTRAK. Kemampuan pemecahan masalah pada saat ini masih tergolong rendah. Masih banyak siswa yang kesulian dalam memahami permasalahan yang terdapat dalam soal matematika, diantaranya belum terbiasa dengan bentuk soal-soal pemecahan masalah. Berdasarkan hasil observasi peneliti dan mengingat pembelajaran matematika yang terlaksana masih cenderung berpusat pada guru. Maka diperlukan suatu metode pembelajaran yang lebih berpusat pada siswa, merangsang, mendorong, dan memfasilitasi siswa untuk bisa menyelesaikan soal-soal tidak rutin yang pada akhirnya dapat meningkatkan kemampuan pemecahan masalah matematis siswa. Brainstorming merupakan alternatif yang tepat karena metode tersebut berorientasi pada kemampuan siswa untuk mengemukakan ide sebanyak mungkin dalam pemecahan suatu persoalan.Penelitian ini bertujuan untuk mengetahui pengaruh metode pembelajaran Brainstorming terhadap kemampuan pemecahan masalah matematika siswa pada materi spldv dan mengetahui respon siswa setelah mengikuti pembelajaran dengan menggunakan metode pembelajaran Brainstorming. Jenis penelitian yang digunakan adalah penelitian eksperimen dengan desain one group pretest-posttest. Sampel dalam penelitian ini dipilih menggunakan teknik purposive sampling. Dari 9 kelas VIII SMP Negeri 15 Ambon kelas VIII-6 dengan jumlah siswa 31 siswa dipilih sebagai sampel untuk penelitian ini. Teknik analisis data yang digunakan adalah teknik analisis inferensial dan analisis deskriptif. Uji yang digunakan adalah uji paired sample t-test. Berdasarkan hasil analisis data menggunakan uji paired sample t-test diperoleh nilai signifikan 0,001 . Yang berarti nilai signifikan $0,001<$ alpha 0,05 . Maka $\mathrm{H}_{1}$ diterima dan $\mathrm{H}_{0}$ ditolak. Dengan demikian terdapat pengaruh signifikan penggunaan metode pembelajaran brainstorming terhadap kemampuan pemecahan masalah matematika siswa.
\end{abstract}

Kata kunci: brainstorming, pemecahan masalah, spldv

ABSTRACT. The ability to solve problems at this time is still relatively low. There are still many students who have difficulty understanding the problems contained in mathematical problems, including those not yet familiar with the form of problem solving problems. Based on the results of observations by researchers and given the mathematics learning that is carried out it still tends to be teacher-centered. So we need a learning method that is more student-centered, stimulates, encourages, and facilitates students to be able to solve non-routine problems that can ultimately improve students' mathematical problem solving abilities. Brainstorming is an appropriate alternative because the method is oriented to the ability of students to express as many ideas as possible in solving a problem. This study aims to determine the effect of Brainstorming learning methods on students 'mathematical problem solving abilities on spldv material and find out students' responses after participating in learning using the method Brainstorming learning. This type of research is an experimental research design with one group pretest-posttest. The sample in this study was selected using purposive sampling technique. Out of 9 classes VIII of SMP Negeri 15 Ambon in class VIII-6 with 31 students, students were selected as samples for this study. The data analysis technique used is inferential analysis and descriptive analysis techniques. The test used is a paired sample t-test. Based on the results of data analysis using paired sample t-test, a significant value of 0.001 was obtained. Which means a significant value of $0.001<$ alpha 0.05 . Then $\mathrm{H} 1$ is accepted and $\mathrm{H} 0$ is rejected. Thus there is a significant influence on the use of brainstorming learning methods on students' mathematical problem solving abilities.

Keywords: brainstorming, problem solving, system of two-variable linear equations 


\section{Pendahuluan}

Pendidikan mempunyai peranan penting dalam keseluruhan aspek kehidupan manusia. Salah satu ilmu yang memegang peranan penting dalam aspek kehidupan manusia adalah matematika. Banyak permasalahan dalam kehidupan yang diselesaikan dengan menggunakan ilmu matematika seperti menghitung, mengukur dll. Pendapat ini sejalan dengan pendapat yang dikemukakan oleh Afrilianto (2012: 193) yang mengatakan bahwa matematika merupakan salah satu disiplin ilmu dalam dunia pendidikan yang memegang peranan penting dalam perkembangan sains dan teknologi.

Depdiknas (Zahra, 2016: 1) matematika merupakan ilmu universal yang mendasari perkembangan teknologi modern, mempunyai peran penting dalam berbagai disiplin ilmu dan memajukan daya pikir manusia. Perkembangan pesat dibidang teknologi informasi dan komunikasi dewasa ini dilandasi oleh perkembangan matematika di bidang teori bilangan, aljabar, analisis, teori peluang, dan matematika diskrit. Oleh karena itu, untuk menguasai dan memanfaatkan teknologi di masa depan diperlukan penguasaan matematika yang kuat sejak dini. Romberg (Widjajanti: 2009) menyebutkan lima tujuan belajar matematika bagi siswa yaitu: (1) belajar nilai tentang matematika, (2) menjadi percaya diri dengan kemampuannya sendiri, (3) menjadi pemecah masalah matematika, (4) belajar untuk berkomunikasi secara matematis, (5) belajar untuk bernalar secara matematis. Dari pendapat tersebut dapat diketahui bahwa pemecahan masalah ikut mengambil peran penting di dalamnya.

Menurut Goenawan (2017: 2) Proses pemecahan masalah menjadi bagian yang penting yang tidak terpisahkan dalam proses pembelajaran matematika. Dalam kehidupan sehari-hari kita selalu menghadapi banyak masalah. Permasalahan-permasalahan itu tentu saja tidak semuanya merupakan masalah matematis, tetapi matematika memiliki peranan yang sangat sentral dalam menjawab permasalahan keseharian itu. Oleh karena itu, cukup beralasan jika pemecahan masalah menjadi "tren" dalam pembelajaran matematika. Pemecahan masalah merupakan bagian dari kurikulum matematika yang sangat penting karena dalam proses pembelajaran siswa dimungkinkan memperoleh pengalaman menggunakan pengetahuan serta keterampilan yang sudah dimilikinya untuk diterapkan pada pemecahan masalah yang bersifat tidak rutin.

Dalam kenyataannya, kemampuan pemecahan masalah pada saat ini masih rendah. Siswa masih kesulitan dalam memahami permasalahan yang terdapat dalam soal matematika, diantaranya belum terbiasa dengan bentuk soal pemecahan masalah. Pendapat di atas diperkuat dengan hasil observasi yang dilakukan peneliti pada saat turun PPL 2 di SMP Negeri 15 Ambon bahwa sebagian besar siswa masih kurang kemampuan pemecahan masalahnya terutama dalam menyelesaikan soal-soal cerita dalam materi SPLDV. Siswa masih kesulitan dalam membuat model matematika. Peneliti memilih materi SPLDV karena (1) materi SPLDV merupakan salah satu materi yang dianggap sukar pada pelajaran matematika, (2) materi SPLDV merupakan salah satu materi yang sangat berkaitan dengan proses pemecahan masalah. Kemampuan pemecahan masalah akan sangat terlihat saat siswa tersebut menyelesaikan soal-soal terutama soal cerita.

Berdasarkan hasil observasi peneliti dan mengingat pembelajaran matematika yang terlaksana masih cenderung berpusat pada guru, serta siswa dibiarkan puas dengan hanya mengerjakan soal-soal rutin, maka diperlukan suatu metode pembelajaran yang lebih berpusat pada siswa, merangsang, mendorong, dan memfasilitasi siswa untuk bisa menyelesaikan soal-soal tidak rutin yang pada akhirnya dapat meningkatkan kemampuan pemecahan masalah matematis siswa. Brainstorming merupakan alternatif yang tepat karena metode tersebut berorientasi pada kemampuan siswa untuk mengemukakan ide sebanyak mungkin dalam pemecahan suatu persoalan. Dengan kata lain, brainstorming adalah salah satu upaya untuk mengembangkan kemampuan berpikir kreatif siswa dalam menyelesaikan suatu masalah.

\section{Metode}

Jenis penelitian yang digunakan adalah penelitian eksperimen dengan desain one group pretest-posttest. Sampel dalam penelitian ini dipilih menggunakan teknik purposive sampling. Dari 9 kelas VIII SMP Negeri 15 Ambon kelas VIII-6 dengan jumlah siswa 31 siswa dipilih sebagai sampel untuk penelitian ini. Instrumen penelitian yang digunakan adalah tes kemampuan pemecahan masalah (tes awal dan tes akhir). Uji yang digunakan adalah uji paired sample t-test. 


\section{Hasil Penelitian}

\subsection{Hasil}

Data hasil penelitian ini diperoleh dari hasil tes kemampuan pemecahan masalah matematika siswa. Analisis ini dilakukan dengan tahap uji normalitas terlebih dahulu kemudian dilanjutkan dengan uji homogenitas dan terakhir dengan uji paired sample t-test.

\section{a. Uji Normalitas Data}

Uji normalitas data dimaksudkan untuk mengetahui sampel yang digunakan normal atau tidak. Perhitungan uji normalitas dengan menggunakan uji one sample Kolmogrov Smirnov dan diperoleh hasil pada tabel berikut:

\begin{tabular}{|c|c|c|c|c|c|c|}
\hline \multicolumn{7}{|c|}{ Tests of Normality } \\
\hline \multirow[t]{2}{*}{ Kelas VIII SMP Negeri 15 Ambon } & \multicolumn{3}{|c|}{ Kolmogorov-Smirnov $^{\mathrm{a}}$} & \multicolumn{3}{|c|}{ Shapiro-Wilk } \\
\hline & Statistic & Df & Sig. & Statistic & $\mathrm{Df}$ & Sig. \\
\hline Pre Test & .115 & 31 & $.200^{*}$ & .963 & 31 & .342 \\
\hline Post Test & .132 & 31 & .184 & .958 & 31 & .265 \\
\hline
\end{tabular}

Dari tabel di atas dapat dilihat bahwa untuk hasil pretest, dengan nilai sig $=0,342>\alpha=0,05$. Sedangkan hasil posttes, nilai sig $=0,265$. Hal ini berarti bahwa $\mathrm{H}_{0}$ diterima dan $\mathrm{H}_{1}$ ditolak. Dengan demikian dapatkan disimpulkan bahwa data penelitian yang diambil berdistribusi normal.

\section{b. Uji Homogenitas}

Uji homogenitas untuk mengetahui data variabel $\mathrm{X}$ dan $\mathrm{Y}$ berasal dari varians yang homogen atau tidak. Uji yang digunakan adalah uji Fishers untuk membandingkan varians kedua variabel. Hasil pengujiannya ditunjukkan pada tabel berikut:

\begin{tabular}{|c|c|c|c|}
\hline \multicolumn{4}{|c|}{ Test of Homogeneity of Variances } \\
\hline Hasil Belajar Siswa \\
\hline Levene Statistic & df1 & df 2 & Sig. \\
\hline 2.762 & 1 & 60 & .102 \\
\hline
\end{tabular}

Dari tabel di atas terlihat bahwa sig $=0,102>\alpha=0,05$. Hal ini menunjukan bahwa $\mathrm{H}_{0}$ diterima dan $\mathrm{H}_{1}$ ditolak sehingga dapat dikatakan varians kedua variabel dalam penelitian ini homogen. Dengan demikian analisi data dengan menggunakan uji paired sample t test dapat digunakan.

c. Uji hipotesis

Uji hipotesis yang digunakan dalam penelitian adalah teknik analisis data paired sample t-test. Uji ini dugunakan untuk mengetahui pengaruh penggunaan metode pembelajaran brainstorming terhadap kemampuan pemecahan masalah matematika siswa pada materi SPLDV di kelas VIII SMP N 15 Ambon. Setelah data dianalisis menggunakan SPSS, adapun hasilnya seperti pada tabel berikut

\begin{tabular}{|c|c|c|c|c|c|}
\hline \multicolumn{5}{|c|}{ Paired Samples Statistics } \\
\hline \multirow{2}{|c|}{} & Mean & N & Std. Deviation & Std. Error Mean \\
\hline \multirow{2}{*}{ Pair 1 } & Nilai Pre Test & 55.97 & 31 & 18.377 & 3.301 \\
\cline { 2 - 6 } & Nilai Post Test & 70.45 & 31 & 12.858 & 2.309 \\
\hline
\end{tabular}


Pada output di atas diperlihatkan ringkasan hasil statistik deskriptif dari kedua sampel yang diteliti yakni pretest dan post-test. Untuk nilai pre-test diperoleh rata-rata hasil belajar atau mean sebesar 55,97 sedangkan untuk nilai post-test diperoleh nilai rata-rata hasil belajar sebesar 70,45. Jumlah responden atau siswa yang digunakan sebagai sampel penelitian sebanyak 31 orang. Karena nilai rata-rata hasil belajar pada pre-test $55,97<$ post-test 70,45, maka artinya secara deskriptif ada perbedaan rata-rata hasil belajar antara pre-test dengan post-test. Selanjutnya untuk membuktikan apakah perbedaan tersebut benar-benar nyata (signifikan) atau tidak, maka perlu menafsirkan hasil uji paired sample t test yang terdapat pada tabel output "Paired sample test"

\begin{tabular}{|c|c|c|c|c|}
\hline \multicolumn{7}{|c|}{ Paired Samples Correlations } \\
\hline \multicolumn{2}{|c|}{} & N & Correlation & Sig. \\
\hline Pair 1 & Nilai Pre Test \& Nilai Post Test & 31 & .100 & .594 \\
\hline
\end{tabular}

Ouput di atas menunjukan hasil korelasi atau hubungan antara kedua data atau hubungan variabel pre test dengan variabel post test. Berdasarkan output di atas diketahui nilai koefisien korelasi (Correlation) sebesar 0,100 dengan nilai signifikansi (sig) sebesar 0,594. Karena nilai sig 0,594 >0,05, maka dapat dikatakan bahwa tidak ada hubungan antara variabel pre test dengan variabel post test.

\begin{tabular}{|c|c|c|c|c|c|c|c|c|}
\hline \multicolumn{9}{|c|}{ Paired Samples Test } \\
\hline & \multicolumn{5}{|c|}{ Paired Differences } & \multirow[t]{3}{*}{$\mathrm{T}$} & \multirow[t]{3}{*}{$\overline{\mathrm{Df}}$} & \multirow{3}{*}{$\begin{array}{l}\text { Sig. }(2- \\
\text { tailed) }\end{array}$} \\
\hline & \multirow[t]{2}{*}{ Mean } & \multirow[t]{2}{*}{$\begin{array}{c}\text { Std. } \\
\text { Deviation }\end{array}$} & \multirow[t]{2}{*}{$\begin{array}{l}\text { Std. Error } \\
\text { Mean }\end{array}$} & \multicolumn{2}{|c|}{$\begin{array}{l}\text { 95\% Confidence Interval of the } \\
\text { Difference }\end{array}$} & & & \\
\hline & & & & Lower & Upper & & & \\
\hline $\begin{array}{l}\text { Nilai Pre Test - Nilai } \\
\text { Post Test }\end{array}$ & -14.484 & 21.354 & 3.835 & -22.317 & -6.651 & -3.776 & 30 & .001 \\
\hline
\end{tabular}

Pada output terakhir inilah akan ditemukan jawaban dari hipotesis penelitian yang telah dibuat sebelumnya. Berdasarkan tabel output SPSS di atas, diketahui nilai ssig $=0,001<0,05$, maka $\mathrm{H}_{1}$ diterima dan $\mathrm{H}_{0}$ ditolak. Sehingga dapat disimpulkan bahwa ada perbedaan rata-rata hasil pre test dengan post test yang artinya ada pengaruh penggunaan metode pembelajaran brainstorming terhadap kemampuan pemecahan masalah matematika siswa pada materi SPLDV di kelas VIII SMP N 15 Ambon. Dari tabel output di atas juga terdapat nilai mean paired differences adalah sebesar -14,484. Nilai ini menunjukan selisih antara rata-rata nilai pre test dengan post test.

\subsection{Pembahasan}

Penelitian ini dilakukan di SMP N 15 Ambon yang terletak di desa Waelete, Kecamatan Teluk Ambon yang memiliki 21 rombongan belajar yang terdiri dari 7 kelas VII, 7 kelas VIII, dan 7 kelas IX. Penelitian ini hanya melibatkan satu kelas, yaitu kelas eksperimen. Dalam menentukan kelas eksperimen peneliti meminta hasil atau nilai rata-rata ulangan matematika seluruh kelas VIII untuk dijadikan sebagai patokan dalam menentukan kelas eksperimen. Dari nilai rata-rata yang diambil yang terdiri dari 7 kelas yaitu, kelas $\mathrm{VIII}_{1}, \mathrm{VIII}_{2}, \mathrm{VIII}_{3}, \mathrm{VIII}_{4}, \mathrm{VIII}_{5}$, $\mathrm{VIII}_{6}$, $\mathrm{VIII}_{7}$ peneliti memilih kelas $\mathrm{VIII}_{6}$ yang mempunyai nilai rata-rata sedang, sebagai kelas eksperimen dengan nilai rata-rata 56,67 yang berjumlah 31 orang siswa. Kemudian dalam menentukan kelas eksperimen ini peneliti sudah punya ancang-ancang sebelumnya dalam memilih kelas mana yang akan dijadikan kelas eksperimen. Karena peneliti telah mengetahui kemampuan rata-rata siswa yang ada di SMP Negeri 15 Ambon berdasarkan pengalaman waktu turun PPL 2 di sekolah tersebut.

Pada proses pembelajaran kelas eksperimen diajarkan dengan menggunakan metode pembelajaran brainstorming. Secara umum metode pembelajaran brainstorming sudah terlaksana dengan baik, hal ini dapat dilihat dari langkah-langkah metode brainstorming, yakni tahap pemberian informasi dan motivasi, identifikasi, 
klarifikasi, verifikasi serta konklusi. Dalam metode pembelajaran brainstorming siswa dilatih untuk dapat mengeluarkan pendapat sebanyak-banyaknya untuk menyelesaikan suatu permasalahan.

Pada kegiatan inti pembelajaran, pertama guru membagi siswa kedalam kelompok-kelompok belajar. Kelompok belajar terdiri dari 6 kelompok, setiap kelompok terdiri dari 5-6 orang. Selanjutnya guru menjelaskan sedikit materi yang akan dipelajari berdasarkan KD dan indikator. Kemudian dilanjutkan dengan guru membagikan lembar kerja siswa (LKS) kepada masing-masing kelompok dan meminta siswa untuk mengerjakan masalah yang ada pada LKS.

Pada proses menyelesaikan masalah yang terdapat dalam LKS, siswa bekerja berdasarkan langkah-langkah yang terdapat dalam metode pembelajaran brainstorming. Pada tahap pemberian informasi, guru menjelaskan sedikit masalah yang terdapat dalam LKS. Kemudian tahap berikutnya yaitu identifikasi siswa didorong untuk memberikan sumbang saran atau pendapat sebanyak-banyaknya berkaitan dengan solusi penyelesaian masalah yang terdapat dalam LKS. Setelah semua saran pendapat dikumpulkan di ketua kelompok, kemudian ketua kelompok bersama peserta mengklarifikasi jawaban yang masuk dan memilih jawaban terbaik. Setelah itu kelompok mempresentasikan hasil kerja masing-masing kelompok tanpa ada kritik dari kelompok lain. Terakhir guru beserta masing-masing kelompok melihat kembali jawaban yang telah di kerjakan kelompok dan menyepakati jawaban yang dianggap paling benar. Selanjutnya sebelum menutup pembelajaran guru memberikan pekerjaan rumah untuk dikerjakan secara individu dengan tujuan untuk mengetahui sejauh mana pemahaman siswa tentang materi yang sudah diajarkan.

Pada pertemuan ke-enam guru membagikan lembar tes akhir kemampuan pemecahan masalah matematika (post test) untuk dikerjakan oleh masing-masing siswa dan setelah itu dilanjutkan dengan pembagian lembar angket siswa untuk mengetahui respon siswa terhahap pembelajaran setelah diterapkannya metode pembelajaran brainstorming. Berdasarkan hasil penyajian dan analisis data yang telah dilakukan menunjukan adanya perbedaan yang signifikan antara pre test dan post test yang artinya terdapat pengaruh metode pembelajaran brainstorming terhadap kemampuan pemecahan masalah matematika siswa.

\section{Kesimpulan}

Berdasarkan hasil penelitian yang telah dijabarkan, maka dapat diambil kesimpulan bahwa terdapat pengaruh signifikan penggunaan metode pembelajaran brainstorming terhadap kemampuan pemecahan masalah matematika siswa. Hal ini dibuktikan dengan meningkatnya rata-rata skor kemampuan pemecahan masalah matematika siswa sebelum dan sesudah diterapkannya metode pembelajaran brainstorming.

\section{Daftar Pustaka}

Afrilianto. 2012. Peningkatan Pemahaman Konsep dan Kompetensi Strategis Matematis Siswa SMP dengan Pendekatan Metaphorical Thinking. Jurnal Ilmiah Program Studi Matematika STKIP Siliwangi Bandung. Vol.1

Avandi, A.B.2015. Pengaruh Model Pembelajaran Osborn terhadap Hasil Belajar Matematika pada Materi Pokok Bangun Datar Segi Empat Siswa Kelas VII di SMPN 2 Ngunut. Skripsi Tadris Matematika F.Tarbiyah dan Ilmu Keguruan Institut Agama Islam Negeri Tulungagung

Budiyanto, A. 2016. Sintaks 45 Model Pembelajaran dalam Student Centered Learning (SCL). Malang: Universitas Muhammadiyah Malang

Goenawan, R. 2017. Pemecahan Masalah Matematika. Bandung: PT Remaja Rosdakarya

Mukrimah, S.2014. 53 Metode Belajar Dan Pembelajaran. Bandung. UPI

Soleh, M. 2017. Pengaruh Metode Pembelajaran Brainstorming terhadap Kemampuan berpikir Kreatif dan Adversity Quotient Matematis Siswa SMA. Skripsi Pendidikan Matematika FKIP Universitas Pasundan Bandung

Widjajanti, D.J. 2009. Kemampuan Pemecahan Masalah Matematis Mahasiswa Calon Guru Matematika:Apa dan Bagaimana Mengembangkannya. Jurnal Pendidikan Matematika FMIPA Universitas Negeri Yogyakarta

Zahra, C. 2016. Metakognisi Siswa Dalam Pemecahan Masalah Matematika. Yogyakarta: Cv Budi Utama 